\title{
IMPLEMENTASI COVOLUTIONAL NEURAL NETWORK UNTUK FACIAL RECOGNITION
}

\author{
Dhanny Setiawan 1 \\ Andikha Dwi Putra ${ }^{2}$ \\ Kezia Stefani ${ }^{3}$ \\ Jenisa Felisa ${ }^{4}$ \\ 1,2,3,4 Sekolah Tinggi Manajemen Informatika dan Komputer \\ LIKMI Jl. Ir. H. Juanda no 96 Bandung \\ dhanny@likmi.ac.id ${ }^{1}$
}

\begin{abstract}
ABSTRAK
Facial recognition merupakan salah satu teknik biometrik. Teknik yang dapat disebut juga pengenalan wajah ini telah menjadi topik yang cukup diminati untuk diteliti. Pada peneitian ini dilakukan proses pengenalan wajah dengan menggunakan metode CNN (Convolutional Neural Network). Penelitian ini memiliki tujuan untuk mengimplementasikan metode CNN ke dalam pengenalan wajah dengan menggunakan library Tensorflow. Metode ini digunakan karena proses pembelajaran dilakukan dengan mendalam (deep learning). Metode CNN yang digunakan memiliki beberapa lapisan pada proses training yang dilakukan, yaitu lapisan Conv2D, MaxPooling2d, Flatten, dan Dense. Face recognition yang dihasilkan terdapat pendeteksi wajah menggunakan Haar Cascade dengan bantuan library Opencv di dalamnya. Jumlah dataset juga diketahui dapat mempengaruhi hasil pengenalan dan proses pengenalan wajah dengan $\mathrm{CNN}$ juga memerlukan dataset yang besar. Adapun jumlah citra wajah yang digunakan dalam penelitian ini sebanyak 90.000 gambar wajah yang berasal dari 36 himpunan gambar dan menghasilkan tingkat akurasi sebesar $97 \%$.
\end{abstract}

Kata kunci : convolutional neural network, facial recognition, deep learning.

\section{PENDAHULUAN}

Sistem untuk pengenalan identitas perlu mengalami peningkatan dalam hal tingkat akurasi yang lebih baik untuk menangani kejahatan dan pemalsuan identitas. Sistem yang telah terlebih dahulu digunakan seperti token-based system dan knowledge-based. TokenBased memiliki tingkat resiko yang tinggi, seperti pencurian identitas. Knowledge-based juga memiliki tingkat resiko yang tinggi, seperti tidak ingat terhadap kata sandi. Hal ini mengakibatkan sistem pengenalan identitas pada saat ini menggunakan sistem biometrik yang sulit untuk dipalsukan. Sistem tersebut digunakan karena bersifat unik dan spesifik. Biometrik memiliki dua sistem, yaitu perilaku dan fisiologis. Biometrik berdasarkan perilaku, contohnya adalah suara, sedangkan biometrik berdasarkan fisiologis, contohnya adalah tanda tangan, sidik jari dan wajah.

Pengenalan wajah sampai sekarang masih merupakan topik yang menarik untuk diteliti. Pengenalan wajah dapat digunakan untuk berbagai bidang seperti pengendalian akses perbatasan, pengawasan, otentikasi smartphone, forensik, dan layanan online seperti $e$ learning dan e-commerce [1]. Pengenalan wajah juga memiliki masalah seperti berbagai macam posisi gambar wajah yang dapat mengakibatkan bagian mata, hidung maupun telinga tidak terlihat secara keseluruhan. Selain itu, dapat juga terjadi permasalahan tambahan dengan adanya penambahan aksesoris/ tambahan seperti contohnya kacamata dan adanya janggut pada gambar wajah. Faktor yang lain yang juga dapat mempengaruhi akurasi 
pengenalan wajah adalah tingkat pencahayaan, ukuran gambar, dan ekspresi wajah [2]. Salah satu algoritma yang dapat digunakan untuk pengenalan wajah adalah Convolutional Neural Network (CNN) yang merupakan salah satu metode deep learning. CNN adalah salah satu kelas deep feedforward artificial neural networks yang banyak diaplikasikan pada analisis citra [3].

CNN memiliki sistem proses yang mirip dengan proses visual manusia dan memiliki struktur optimasi yang tinggi dalam memproses gambar dua dimensi maupun tiga dimensi. Arsitektur CNN terdiri atas penggabungan dari tiga jenis layers, yaitu lapisan konvolusional (convolution layers), max-pooling, dan classification [4]. Setiap lapisan CNN mentransformasikan volume masukan tiga dimensi ke dalam volume keluaran tiga dimensi aktivasi-aktivasi sel saraf. Berbeda dengan MLP yang arsitekturnya disusun secara dua dimensi, CNN menggunakan arsitektur tiga dimensi, yaitu lebar (width), tinggi (height), dan dalam (depth). Sebagian besar proses komputasi dilakukan di convolutional layer, sedangkan pooling layer berfungsi untuk menjaga ukuran data ketika convolution dengan melakukan pereduksian sampel. Max-pooling merupakan proses pooling yang umum digunakan, yaitu dengan memilih nilai maksimum dalam suatu area tertentu [3].

Tujuan dari penelitian ini adalah untuk melakukan deteksi wajah menggunakan webcam, kemudian melakukan segmentasi terhadap gambar yang diambil, dan melakukan training terhadap gambar tersebut menggunakan algoritma convolutional neural network $(\mathrm{CNN})$ untuk kemudian dilakukan pengujian. Kegunaan dari penelitian ini adalah untuk mendeteksi wajah melalui kamera dan kemudian melakukan pengenalan wajah. Penelitian ini dapat dimanfaatkan di bidang lalu lintas untuk mengenali wajah pelanggar rambu lalu lintas [5] atau untuk penerapan keamanan di sebuah perusahaan dengan menggunakan pengenalan wajah.

\section{LANDASAN TEORI}

\section{2a. Facial Recognition}

Facial Recognition (pengenalan wajah) merupakan bagian dari keamanan informasi berkaitan dengan condentiality, integrity, dan ketersedian informasi. [6] penelitian mengenai pengenalan wajah secara otomatis dapat disebut Automated Face Recognition (AFR) sudah berlangsung dari tahun 1960. Namun, AFR baru populer pada tahun 1990 dan kemudian setelah itu ditemukan Eigenfaces. Beragam model dibangun menggunakan bermacam pendekatan, teknik, dan metode. Tantangan dalam melakukan pengenalan wajah antara lain dari kemiringan wajah, pencahayaan, intensitas cahaya, dan usia. Tahun 2015 menjadi tahun yang penting bagi perkembangan sistem pengenalan wajah, dimana terbentuknya sebuah model pengenalan wajah yang melampaui manusia.

Permasalahan pada pengenalan wajah dibagi menjadi dua bagian, yaitu identifikasi dan verifikasi. Identifikasi diberi masukan sebuah citra wajah dan harus mampu mengidentifikasi citra yang berasal dari wajah yang terdapat pada basis data. Sedangkan verifikasi memasukkan dua citra wajah dan harus memutuskan apakah keduanya berasal dari wajah yang sama.

Biometric dapat dikategorikan menjadi tiga teknik, yaitu physical biometrics, behavioral biometrics dan chemical biometrics. Physical biometrics adalah seperti karakteristik wajah dan sidik jari. Behavioral biometrics adalah hasil pengukuran kerja seseorang seperti tanda tangan, gaya berjalan, dan bicara. Chemical biometrics merupakan pengukuran kimia seperti bau dan komposisi kimia dari keringat manusia.

Menurut Suyanto pengenalan wajah merupakan pengaplikasian dari machine learning yang memiliki basis yang memiliki pendekatan yaitu geometric dan photometric. Pendekatan geometric merupakan pendekatan menggunakan fitur dari posisi mata, posisi 
mulut, bentuk dagu dan sebagainya. Sedangkan untuk pendekatan photometric dengan melakukan proses penyulingan citra wajah secara keseluruhan kedalam nilai dan membandingkan [3].

\section{2b. Deep Learning dan CNN}

Deep learning diperkenalkan di sebuah kompetisi pengenalan citra ImageNet Large Scale Visual Recognition Comparison (ILSVRC) yang diselenggarakan tahun 2012, deep learning menjadi pemenang dengan tingkat akurasi tertinggi [3]. Deep learning dapat diartikan menjadi pembelajaran yang mendalam terdapat teknik dari jaringan saraf tiruan (ANN), merupakan bagian dari machine learning [7].

Artificial Neural Network, Decision tree learning dan sebagainya sebagai pembelajaran secara dangkal, jumlah lapisan terbatas (shallow Learning). Deep learning pengembangan dari Artificial Neural Network terkhusus Multi Layer Perceptron (MLP). MLP memiliki perbedaan dengan Deep Learning yaitu MLP menggunakan konsep jaringan terhubung penuh, sedangkan Deep learning memiliki skema jaringan yang lebih sederhana karena menggunakan filter. Deep learning diterapkan untuk menyelesaikan masalah diantaranya klasifikasi, deteksi, segmentasi, dan mengenerasi gambar dan video dalam pengaplikasian computer vision [7]. Deep learning tedapat algoritma Convolutional Neural Network (CNN), CNN memiliki perbedaan dengan MLP yaitu CNN memiliki berarsitektur tiga dimensi yaitu lebar, tinggi, dan kedalaman sedangkan MLP menggunakan dua dimensi [3].

Convolutional Neural Network dapat membantu menangani variasi yang kompleks dalam gambar dengan mendapatkan nilai akurasi yang lebih tinggi [7]. Bagian - bagian dari CNN diantaranya Convolutional layer, pooling layer dan fully connected layer [8].

a. Convolutional Layer

Lapisan convolutional merupakan lapisan terpenting dengan melakukan proses konvolusi (Convolution). Konvolusi merupakan salah satu istilah pada ilmu matematika [9].

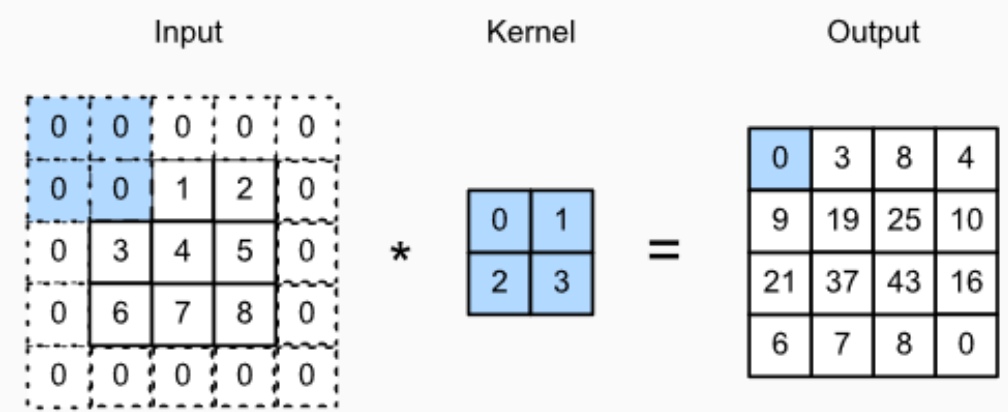

Gambar 1 Contoh Proses Convolution

Pada gambar 1 menunjukan proses convolution dengan input dilakukan proses zero padding [3].

b. Pooling Layer

Lapisan pooling memiliki fungsi dengan melakukan downsampling. Lapisan convolution dan lapisan pooling memiliki fungsi mengurangi dan mencegah overfitting, mengurangi jumlah parameter menjadi mengurangi kompleksitas tanpa kehilangan informasi [10]. Lapisan pooling memiliki beberapa tipe yaitu max pooling, L2-norm pooling dan average pooling. Max pooling memberikan performa lebih baik [3]. Pada Gambar 2 merupakan salah satu contoh max pooling. 


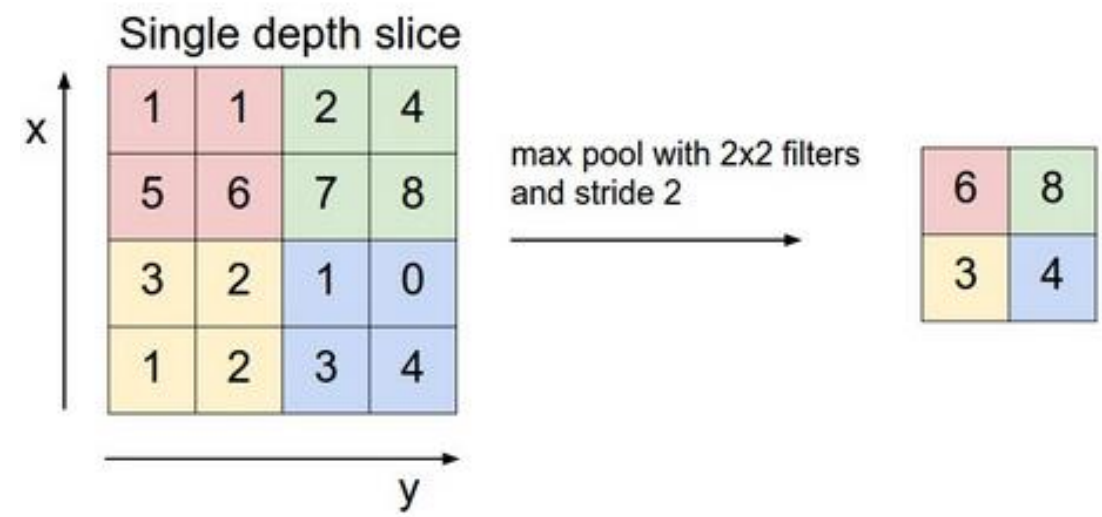

\section{Gambar 2. Contoh Max Pooling}

c. Fully Layer

Lapisan Fully merupakan lapisan yang terhubung sepenuhnya ke semua neuron, lapisan fully sama dengan Multi Layer Perceptron. Pada tahap ini tidak diatur secara spasial mengakibatkan ketika sudah sampai lapisan fully, tidak boleh ditambah lapisan convolution [10]. Komputasi menggunakan suatu perkalian matriks yang diikuti dengan bias offset [3].

\section{HASIL DAN PEMBAHASAN}

Perangkat lunak dirancang berdasarkan pengimplentasian algoritma CNN pada Face Recognition. Sistem akan mendapatkan citra yang akan menjadi dataset dari capture webcam. Kemudian, sebelum proses pengenalan dilakukan, maka dataset yang sudah tersimpan tersebut harus dilatih terlebih dahulu. Library yang digunakan untuk melatih data latih yang sudah tersedia adalah Tensorflow (Keras) dengan algoritma CNN, sedangkan pendeteksi wajah menggunakan library opencv.

Tahapan dimulai dengan proses pendaftaran, di mana dalam proses ini citra wajah akan disimpan pada webcam dan juga dilakukan pemberian label pada citra tersebut. Proses pendeteksian wajah berlangsung ketika pada citra yang tertangkap oleh kamera dapat dikenali objek yang menyerupai wajah manusia. Pada citra tersebut selanjutnya akan diberi tanda berupa border kotak sebagai penunjuk citra wajah.

Terhadap citra wajah yang tersedia akan dilakukan augmentasi data dengan tujuan untuk memperbanyak jumlah data citra dan meminimalisir over-fitting. Proses training sendiri menggunakan lapisan Conv2D, MaxPooling2d, Flatten, dan Dense. Model training yang digunakan pada percobaan ini berupa model training berulang (sequential). Jumlah dataset yang digunakan dalam pengujian ini adalah 36 orang yang 33 orang diantaranya berasal dari database bollywood celeb face 0 dan 3 orang selanjutnya berasal dari dataset yang dibuat sendiri.

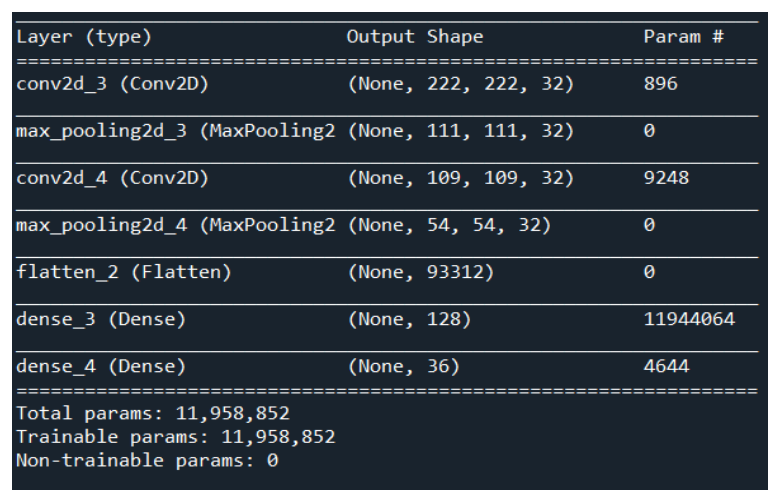

Gambar 3. Model Latih CNN 


\section{3.a Pengujian Model Percobaan}

Pada proses testing Performa dilakukan sebanyak dua kali. Pertama, dengan menggunakan 36 orang dengan jumlah 16.704 data yang di-training. Jumlah data uji yang digunakan sebanyak 1.800, mendapatkan hasil 66\%. Pengujian performa dengan menggunakan GPU dengan epoch 5 dan step per epoch 350.

\section{Tabel 1}

\section{Hasil Evaluasi Percobaan Pertama}

\begin{tabular}{|c|c|c|c|c|}
\hline No. & Nama & Jumlah Data uji & Pression & recall \\
\hline 1 & Aamir & 50 & 0,64 & 0,63 \\
\hline 2 & Abhay & 50 & 0,7 & 0,73 \\
\hline 3 & Abhishek & 50 & 0,76 & 0,58 \\
\hline 4 & Aftab & 50 & 0,58 & 0,56 \\
\hline 5 & Aishwarya & 50 & 0,7 & 0,78 \\
\hline 6 & Ajay & 50 & 0,6 & 0,64 \\
\hline 7 & Akshay & 50 & 0,66 & 0,61 \\
\hline 8 & Akshaye & 50 & 0,78 & 0,59 \\
\hline 9 & Alia & 50 & 0,72 & 0,88 \\
\hline 10 & Ameesha & 50 & 0,56 & 0,57 \\
\hline 11 & Amitabh & 50 & 0,7 & 0,78 \\
\hline 12 & Amrita & 50 & 0,6 & 0,61 \\
\hline 13 & Amy & 50 & 0,68 & 0,63 \\
\hline 14 & Anil & 50 & 0,66 & 0,66 \\
\hline 15 & Anushka_sharma & 50 & 0,66 & 0,67 \\
\hline 16 & Anushka_Shetty & 50 & 0,6 & 0,5 \\
\hline 17 & Arjun_Kapoor & 50 & 0,76 & 0,75 \\
\hline 18 & Arjun_Rampal & 50 & 0,66 & 0,72 \\
\hline 19 & Arshad & 50 & 0,62 & 0,62 \\
\hline 20 & Asin & 50 & 0,56 & 0,62 \\
\hline 21 & Ayushmann & 50 & 0,72 & 0,77 \\
\hline 22 & Bhumi & 50 & 0,58 & 0,64 \\
\hline 23 & Bipasha & 50 & 0,66 & 0,75 \\
\hline 24 & Bobby & 50 & 0,72 & 0,82 \\
\hline 25 & Deepika & 50 & 0,66 & 0,72 \\
\hline 26 & Disha & 50 & 0,72 & 0,75 \\
\hline 27 & Emraan & 50 & 0,66 & 0,65 \\
\hline 28 & Esha & 50 & 0,72 & 0,86 \\
\hline 29 & Farhan & 50 & 0,6 & 0,65 \\
\hline 30 & Govinda & 50 & 0,72 & 0,73 \\
\hline 31 & Hrithik & 50 & 0,62 & 0,65 \\
\hline 32 & Huma & 50 & 0,6 & 0,6 \\
\hline 33 & Ileana & 50 & 0,8 & 0,78 \\
\hline 34 & Andikha & 50 & 0,58 & 0,56 \\
\hline 35 & Bill Gates & 50 & 0,62 & 0,5 \\
\hline 36 & Elon Musk & 50 & 0,698 & 0,6 \\
\hline
\end{tabular}




$$
\text { overall accurcy }=\frac{1189}{1800} \times 100 \%=66,06 \%
$$

Pada proses testing kedua dilanjutkan masih dengan menggunakan 36 orang dengan jumlah diperbanyak dengan teknik augmentasi. Dengan total data traning 90.000 wajah. Data uji yang digunakan dengan total 18.000 wajah. Dengan tidak merubah epoch dan step per epoch. Dapat dilihat pada gambar 17 dengan hasil $97 \%$.

Tabel 2

Hasil Evaluasi Percobaan Kedua

\begin{tabular}{|c|c|c|c|c|}
\hline No. & Nama & $\begin{array}{c}\text { Jumlah } \\
\text { Data }\end{array}$ & Presision & recall \\
\hline 1 & Aamir & 500 & 0,968 & 0,968 \\
\hline 2 & Abhay & 500 & 0,972 & 0,98 \\
\hline 3 & Abhishek & 500 & 0,962 & 0,958 \\
\hline 4 & Aftab & 500 & 0,972 & 0,978 \\
\hline 5 & Aishwarya & 500 & 0,974 & 0,98 \\
\hline 6 & Ajay & 500 & 1 & 0,996 \\
\hline 7 & Akshay & 500 & 0,966 & 0,966 \\
\hline 8 & Akshaye & 500 & 0,992 & 0,982 \\
\hline 9 & Alia & 500 & 0,972 & 0,984 \\
\hline 10 & Ameesha & 500 & 0,964 & 0,962 \\
\hline 11 & Amitabh & 500 & 0,982 & 0,986 \\
\hline 12 & Amrita & 500 & 0,966 & 0,976 \\
\hline 13 & Amy & 500 & 0,982 & 0,992 \\
\hline 14 & Anil & 500 & 0,962 & 0,962 \\
\hline 15 & Anushka_sharma & 500 & 0,982 & 0,98 \\
\hline 16 & Anushka_Shetty & 500 & 0,974 & 0,978 \\
\hline 17 & Arjun_Kapoor & 500 & 0,97 & 0,99 \\
\hline 18 & Arjun_Rampal & 500 & 0,984 & 0,978 \\
\hline 19 & Arshad & 500 & 0,996 & 0,992 \\
\hline 20 & Asin & 500 & 0,96 & 0,949 \\
\hline 21 & Ayushmann & 500 & 0,97 & 0,974 \\
\hline 22 & Bhumi & 500 & 0,978 & 0,978 \\
\hline 23 & Bipasha & 500 & 0,992 & 0,992 \\
\hline 24 & Bobby & 500 & 0,982 & 0,984 \\
\hline 25 & Deepika & 500 & 0,986 & 0,976 \\
\hline 26 & Disha & 500 & 0,97 & 0,97 \\
\hline 27 & Emraan & 500 & 0,954 & 0,956 \\
\hline 28 & Esha & 500 & 0,994 & 0,986 \\
\hline
\end{tabular}




\begin{tabular}{|c|c|c|c|c|}
\hline No. & Nama & $\begin{array}{c}\text { Jumlah } \\
\text { Data }\end{array}$ & Presision & recall \\
\hline 29 & Farhan & 500 & 0,998 & 0,963 \\
\hline 30 & Govinda & 500 & 0,96 & 0,978 \\
\hline 31 & Hrithik & 500 & 0,976 & 0,984 \\
\hline 32 & Huma & 500 & 0,95 & 0,963 \\
\hline 33 & Ileana & 500 & 0,97 & 0,962 \\
\hline 34 & Andikha & 500 & 0,954 & 0,952 \\
\hline 35 & Bill Gates & 500 & 0,958 & 0,95 \\
\hline 36 & Elon Musk & 500 & 0,99 & 0,988 \\
\hline
\end{tabular}

$$
\text { Overall accurcy }=\frac{17541}{18000} x 100 \%=97,45 \%
$$

\section{3.b Perancangan Antarmuka}

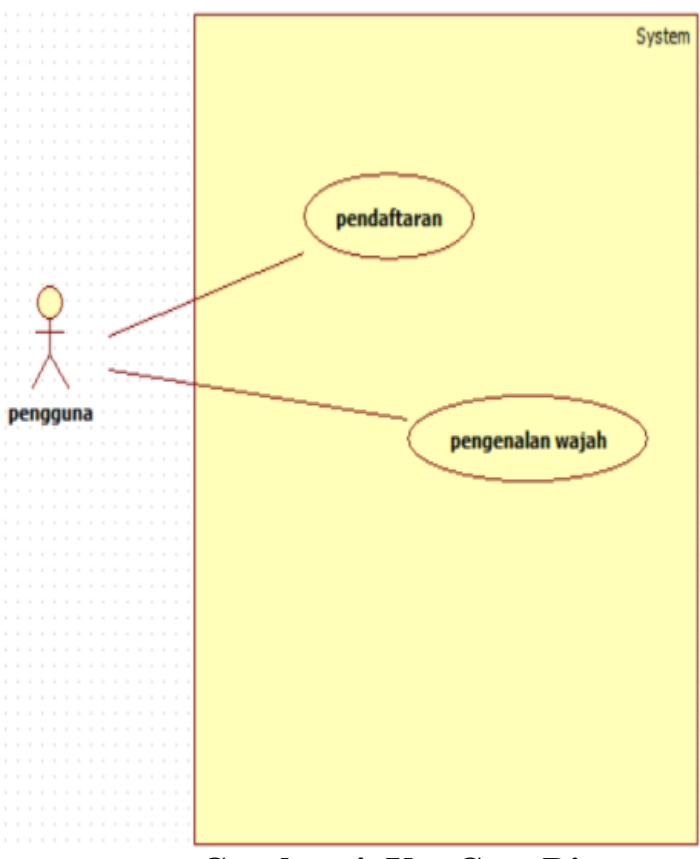

Gambar 4. Use Case Diagram

Pada halaman muka (Gambar 5) ditampilkan tiga buah button (tombol). Tombol pendaftaran yang ditekan akan menampilkan frame pendaftaran. Tombol Deteksi wajah menampilkan frame Deteksi Wajah. Tombol Pengenalan wajah memanggil frame Pengenalan. 


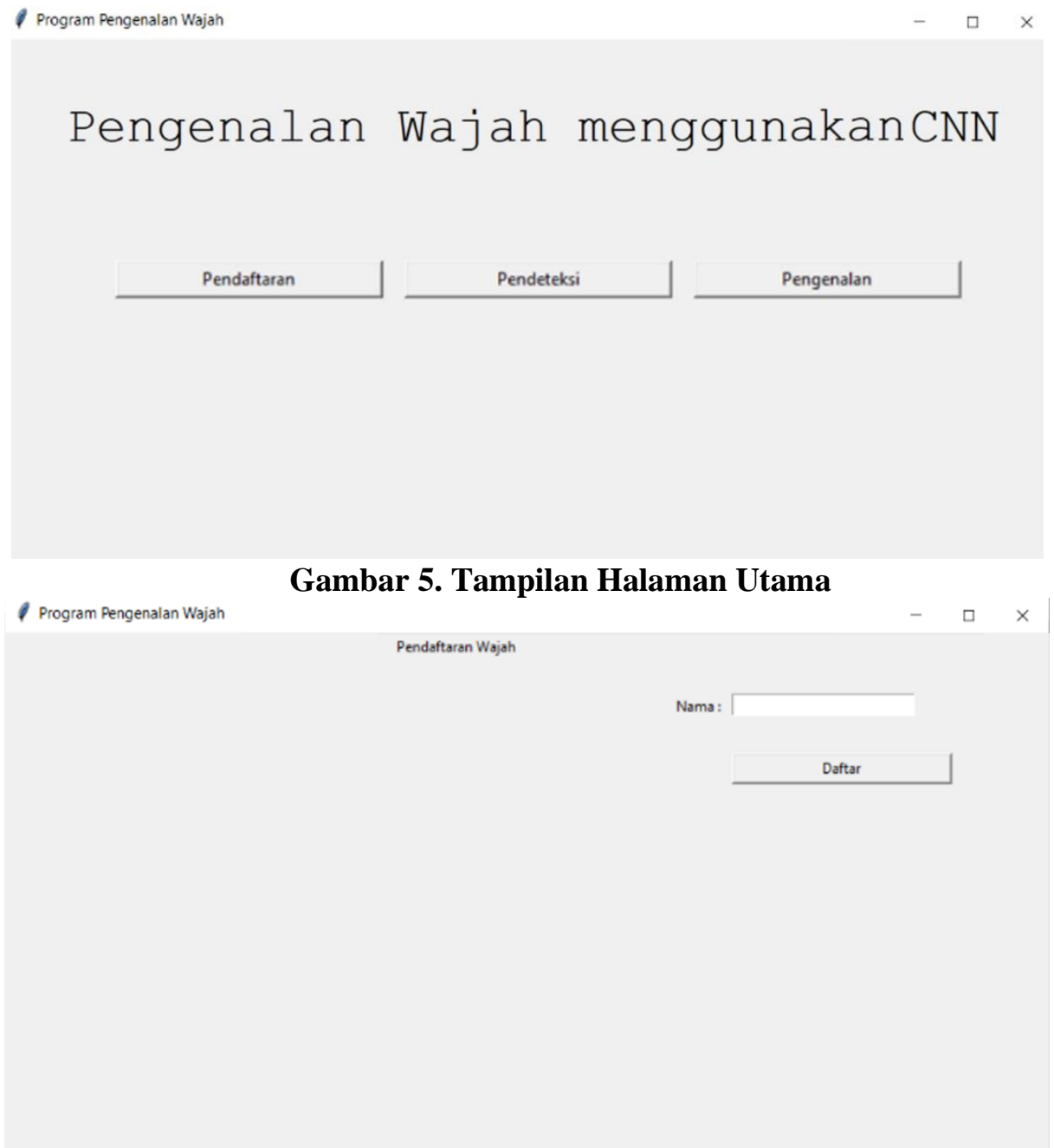

Gambar 6. Tampilan Frame Pendaftaran

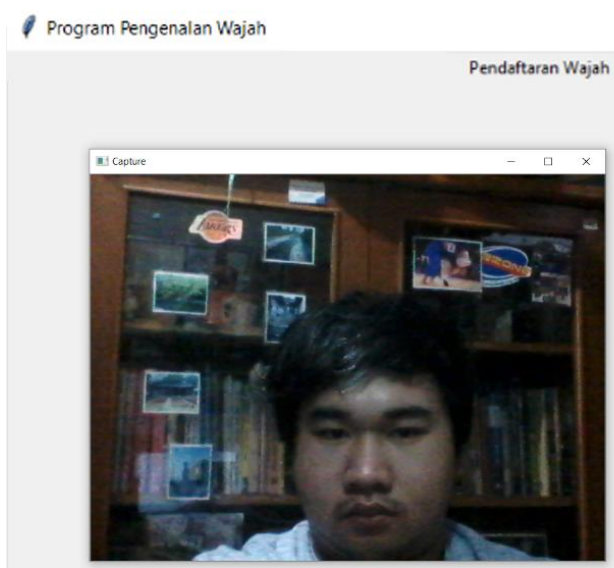

Namo:

Daftar

Gambar 7. Tampilan Ketika Menekan Button Daftar 


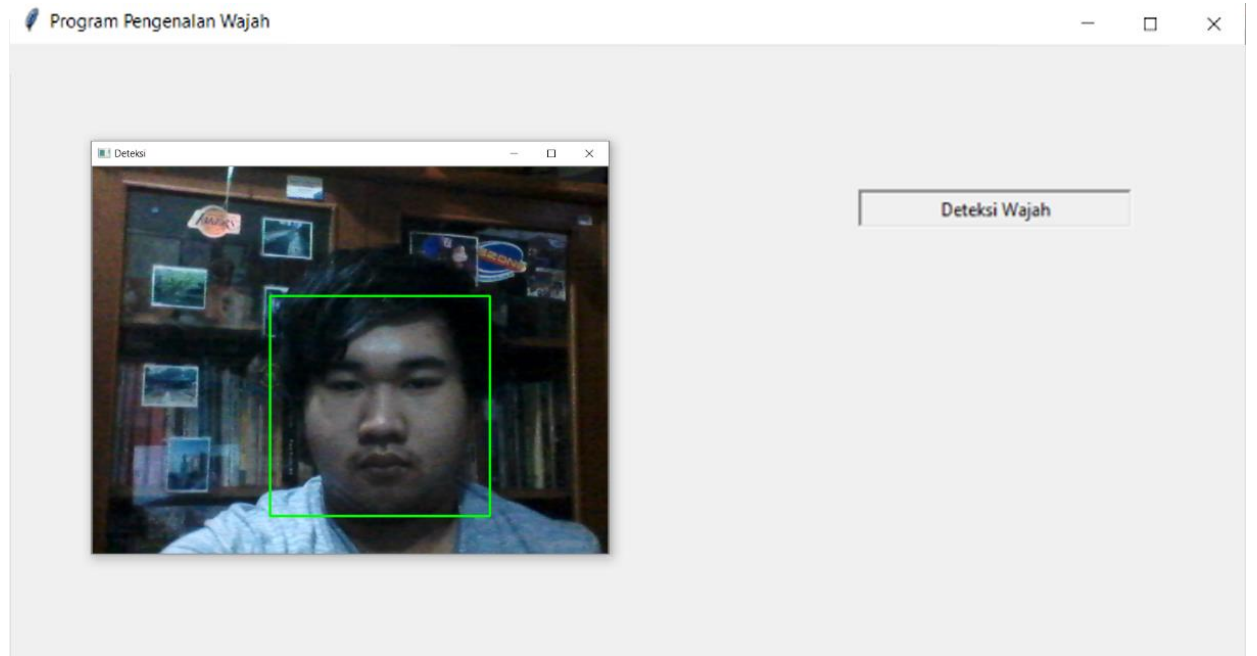

Gambar 8. Tampilan Pendeteksian Wajah

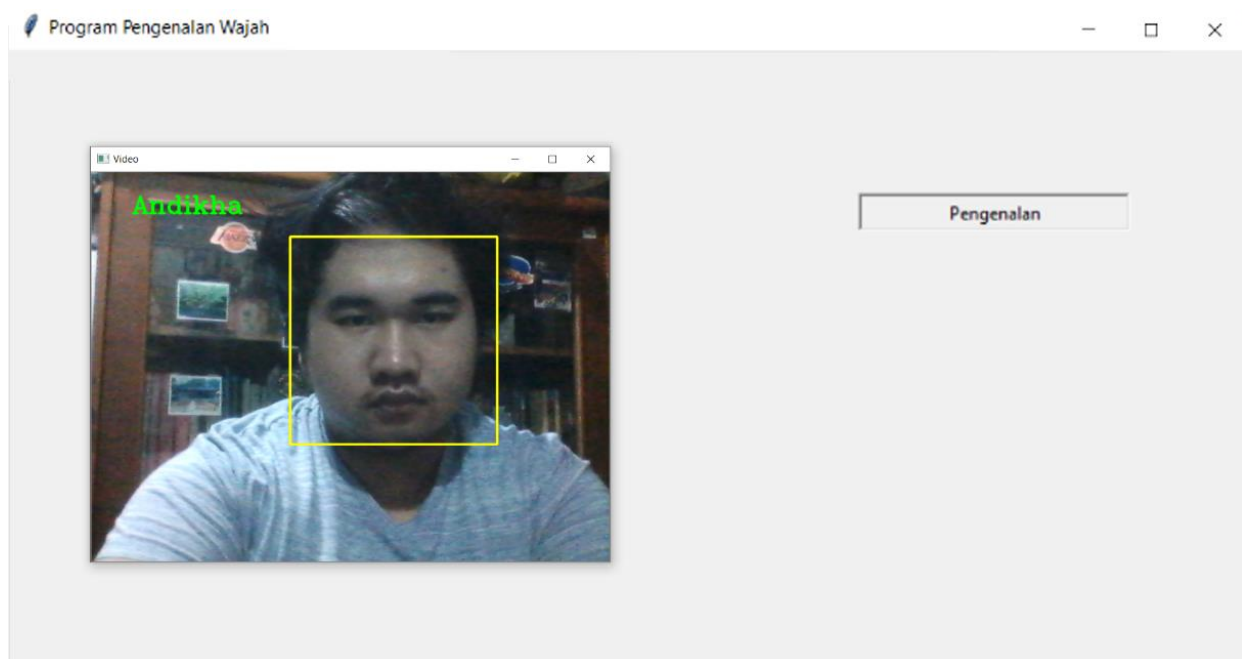

Gambar 9. Tampilan Pengenalan Wajah

\section{3.c Pengujian Facial Recognition secara Real Time}

Pada Gambar 10 berikut, merupakan tampilan pada pengenalan wajah ketika diuji dengan tidak ada wajah pada sorotan webcam.

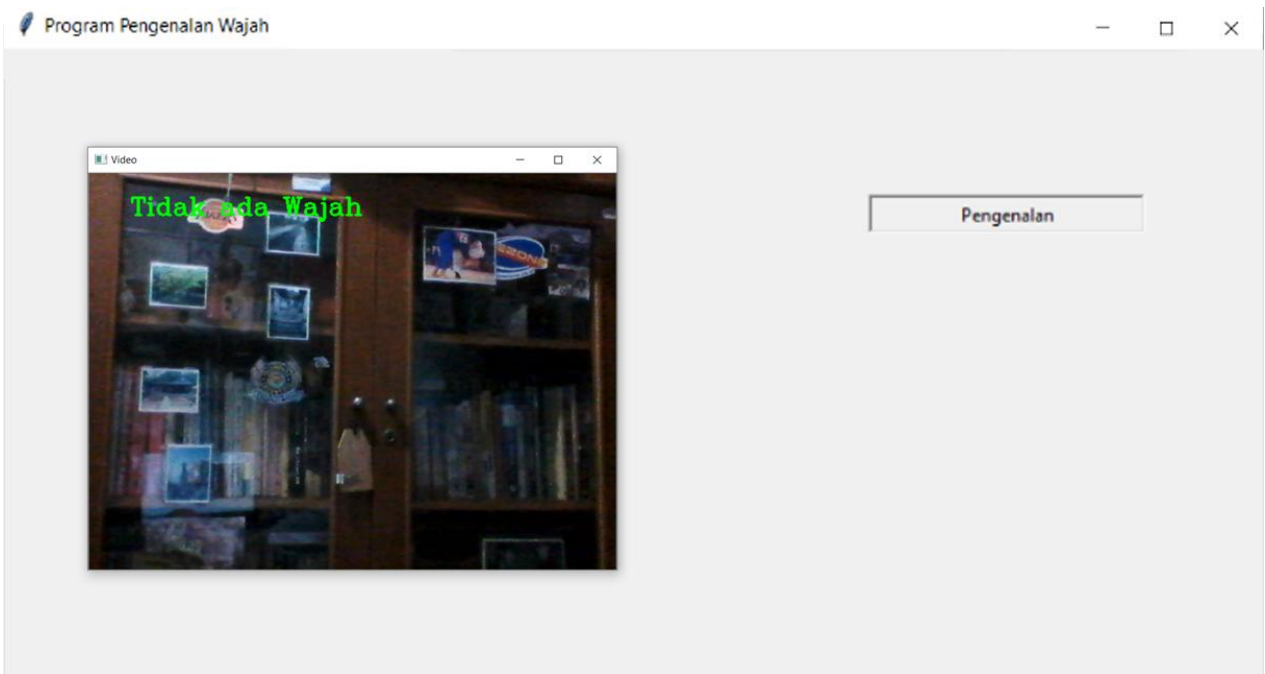

Gambar 10. Pengujian tidak ada wajah 
Selanjutnya (Gambar 11) merupakan tampilan pengujian saat wajah pada posisi mengarah ke bawah (menunduk) yang terlihat dapat dikenali.

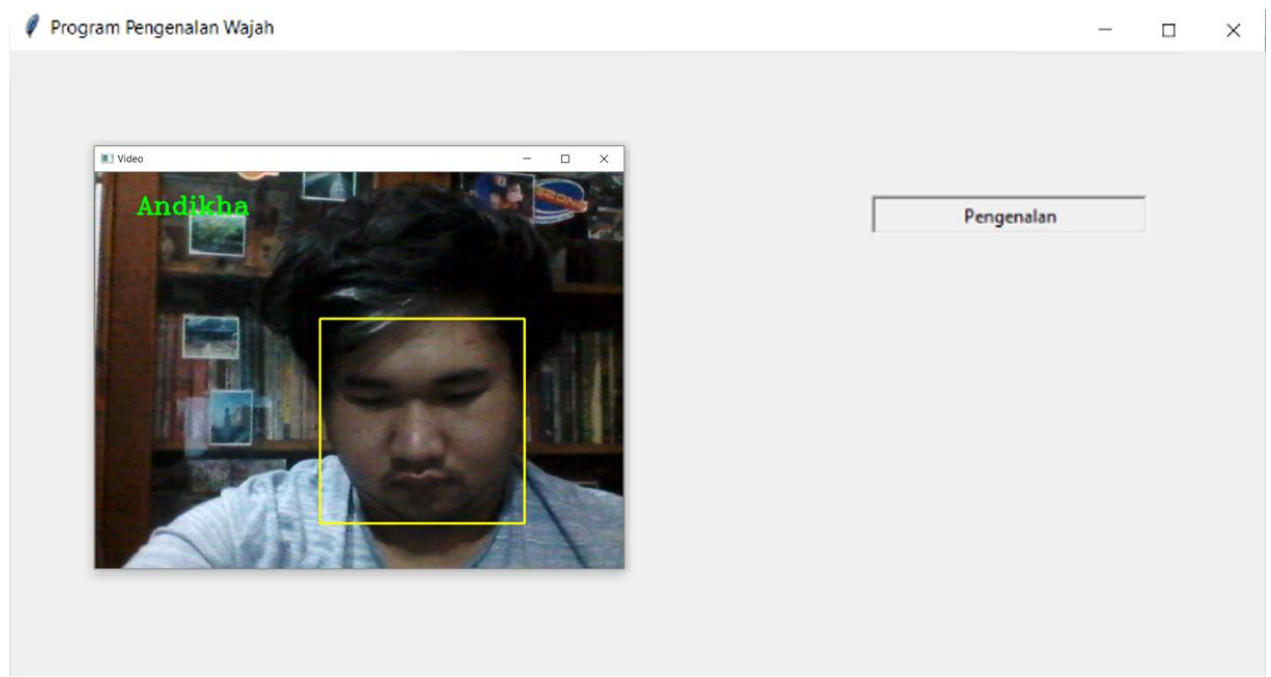

Gambar 11. Pengujian Wajah menghadap ke bawah

Berikut (Gambar 12) saat pengujian dengan wajah menghadap ke sebelah kanan. Tampak citra wajah masih dapat dikenali.

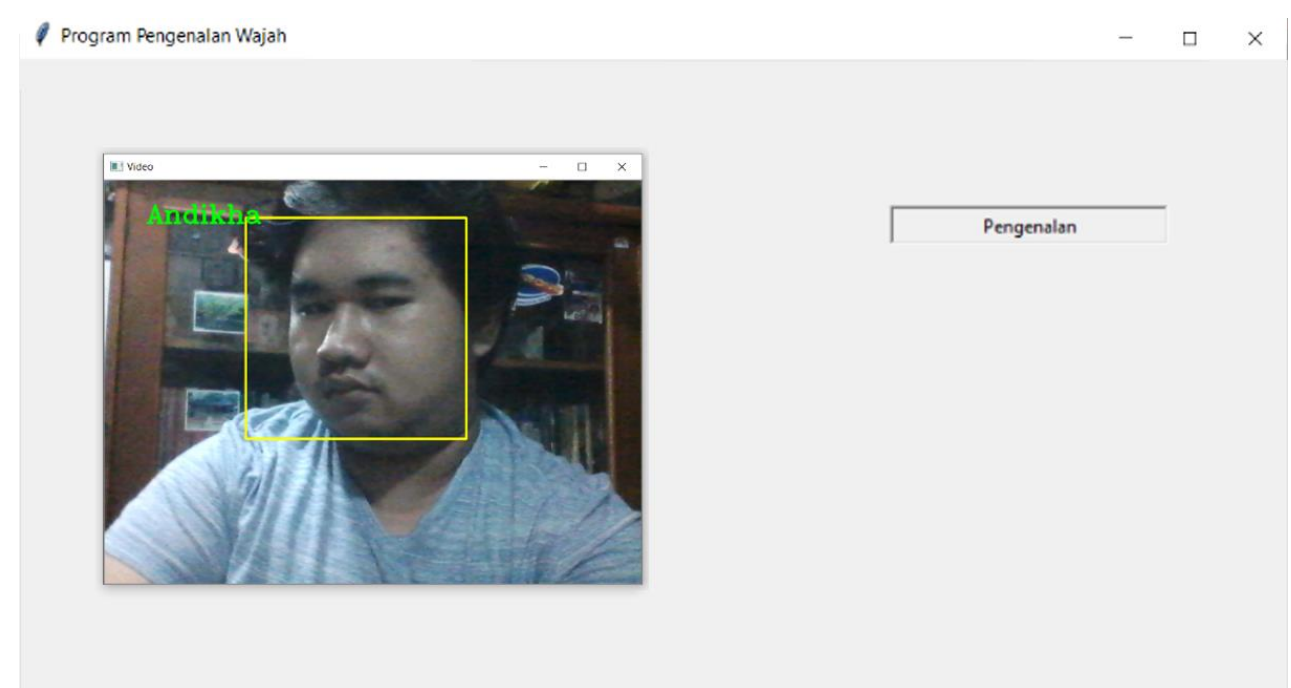

Gambar 12. Wajah menghadap ke sebelah kanan

Pada saat pengujian dimana wajah menghadap ke arah sebelah kiri (Gambar 13), citra masih dapat dikenali. 


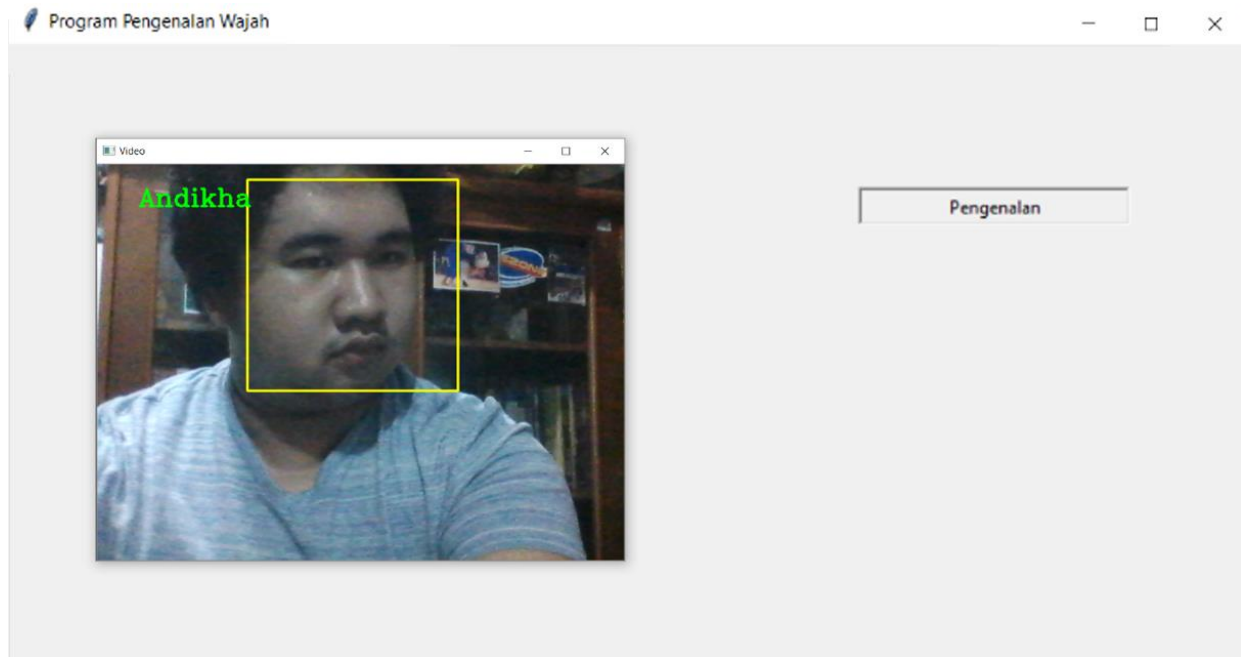

Gambar 13. Wajah menghadap ke sebelah kiri

Gambar berikut (Gambar 14) menampilkan pengujian dengan cara sebelah wajah ditutupi oleh tangan dan hasilnya wajah tidak terdeteksi, mengakibatkan tidak dapat dikenali.

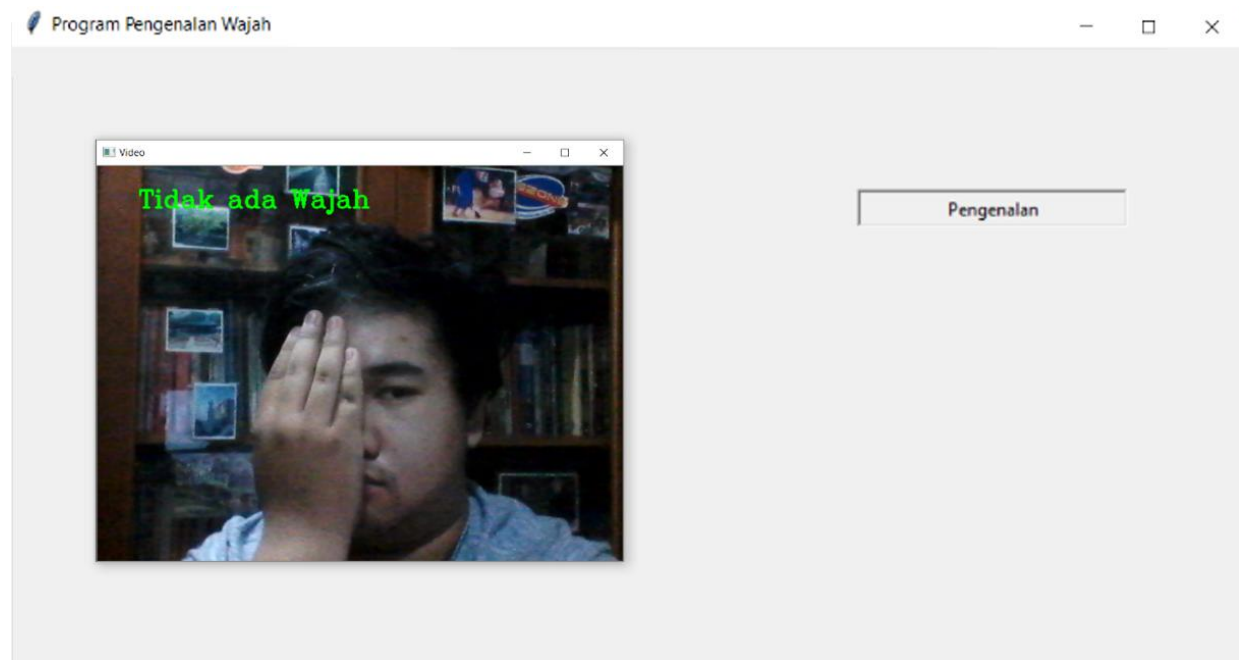

Gambar 14. Wajah ditutupi sebagian tidak dikenali

Berikutnya (Gambar 15) menampilkan pengujian terhadap gambar menggunakan foto pada kartu pengenal mahasiswa dan hasilnya citra dapat terdeteksi namun tidak dikenali.

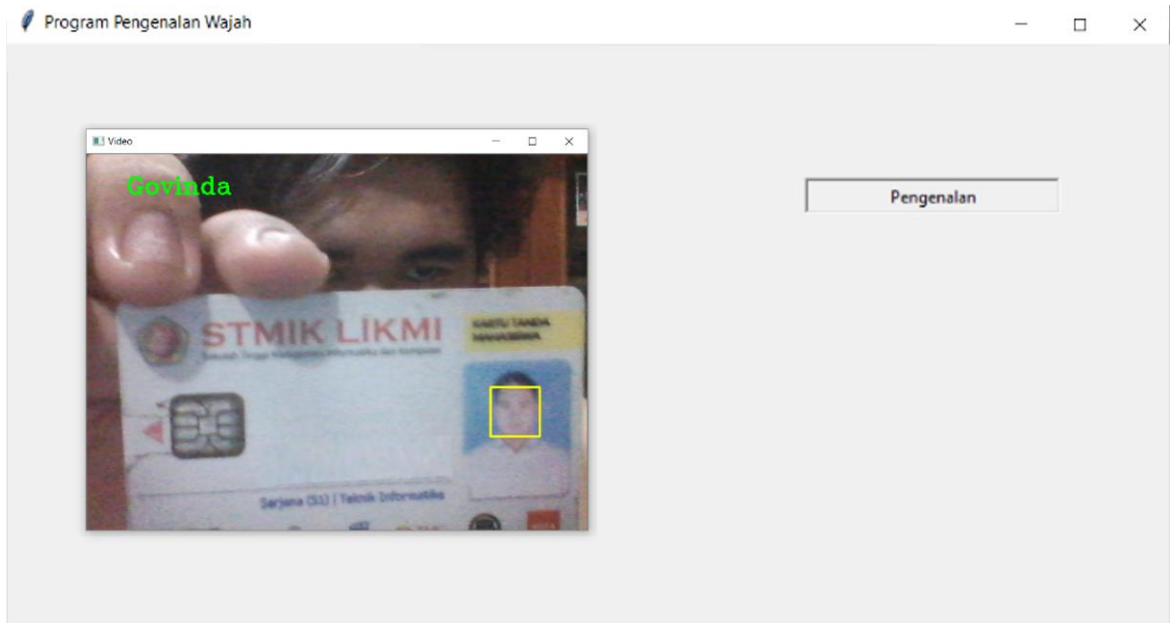

Gambar 15. Hasil pengenalan menggunakan kartu identitas 
Pengujian pada gambar selanjutnya (Gambar 16) menampilkan pengujian dengan pengenalan wajah yang menampilkan gambar wajah yang muncul pada layar Handphone dengan hasil prediksi tidak cocok.

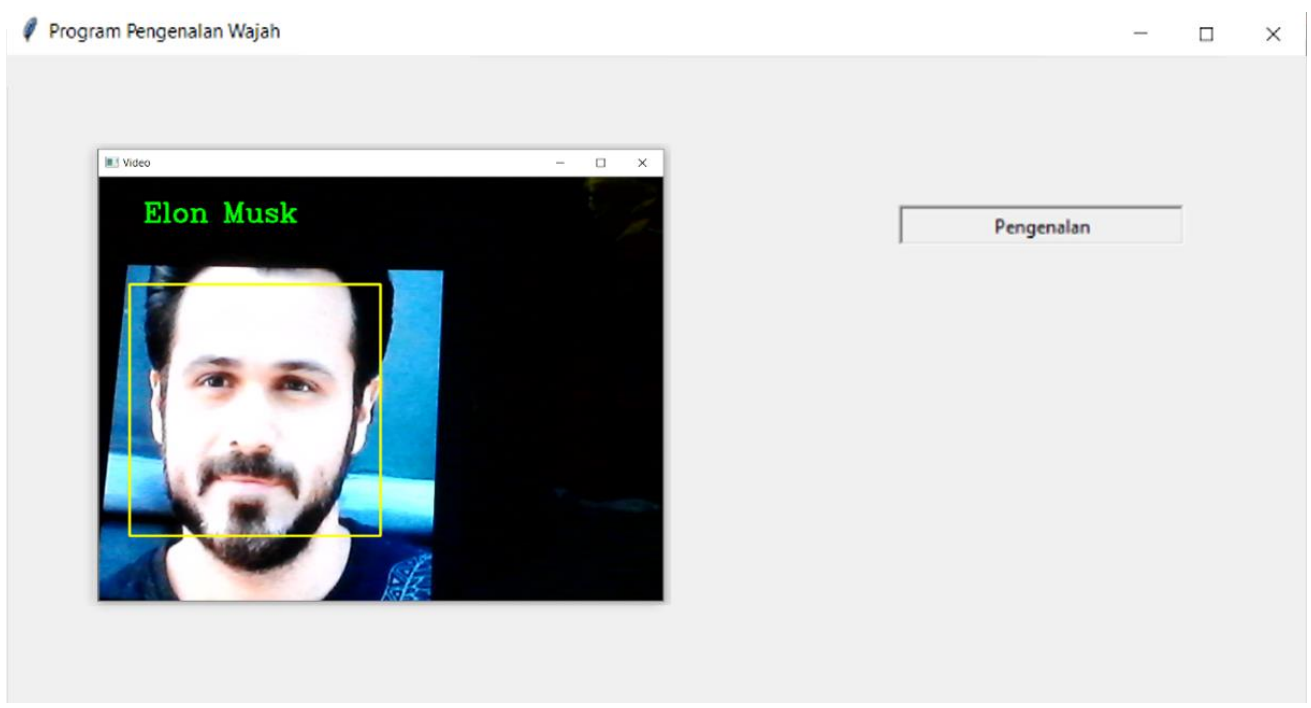

Gambar 16. Pengenalan dari gambar pada layar handphone

Pengujian selanjutnya (Gambar 17) menampilkan pengujian pengenalan wajah dengan menutup kedua mata dengan tangan dan hasilnya wajah tidak terdeteksi.

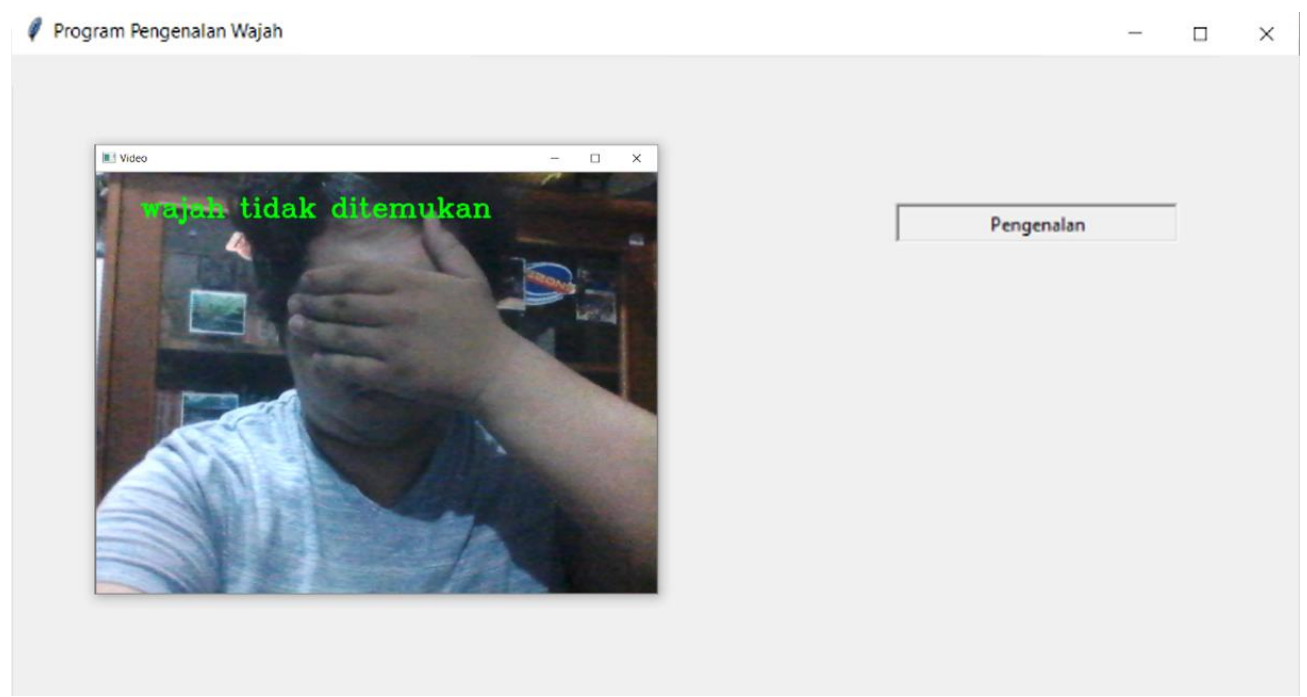

Gambar 17. Pengujian dengan menutup kedua mata

\section{KESIMPULAN}

Berdasarkan hasil penelitian yang sudah dilakukan, kesimpulan yang dapat diambil adalah sebagai berikut :

Hasil yang diperoleh dari penelitian ini adalah kemampuan sistem untuk mendapatkan tingkat akurasi yang cukup tinggi yaitu sebesar 97,64\% dengan menggunakan 5 epoch. Hasil ini lebih baik dari penelitian yang dilakukan sebelumnya dengan pengambilan gambar menggunakan webcam, di mana tingkat akurasi yang diperoleh adalah sebesar $65 \%$ [11] 
Tetapi ada hal lain terjadi pada saat pengujian terhadap wajah yang terdapat dalam kartu pengenal dan wajah yang ditampilkan melalui layar telepon genggam di mana sistem tidak dapat memprediksi wajah dengan benar. Hal tersebut dapat dikarenakan pengenalan wajah merupakan sistem biometrik yang bersifat unik dan tidak bisa dipalsukan.

Dalam pembangunan ini, adapun saran diajukan untuk menjadi masukan dalam Implementasi CNN untuk pengenalan wajah sebagai berikut:

1. Data set yang digunakan atau data yang hendak diuji hendaklah menggunakan jumlah yang banyak karena hal tersebut akan berpengaruh terhadap hasil training dengan jumlah minimal per kelas sebanyak 2000 data gambar.

2. Dalam proses pengembangan selanjutnya, perlu dilakukan penelitian lanjut menggunakan sistem pendeteksi wajah yang mampu menangkap citra wajah dengan lebih baik seperti halnya dalam penerapan menggunakan pendeteksi MT-CNN.

3. Penelitian selanjutnya dapat dikembangkan ke arah pengaplikasian secara langsung, seperti misalnya untuk mengenali penjahat atau pelaku kriminal ataupun dalam aplikasi absensi kehadiran.

\section{DAFTAR PUSTAKA}

[1] J. Hernandez-Ortega, J. Fierrez, A. Morales and J. Galbally, "Introduction to Face Presentation Attack," in Handbook of Biometric Anti-Spoofing: Presentation Attack Detection, Springer, 2019, pp. 187-206.

[2] N. H. Alskeini, K. N. Thanh, V. Chandran and W. Boles, "Face recognition: Sparse Representation vs. Deep Learning," in Proceedings of the 2nd International Conference on Graphics and Signal Processing, Sydney, 2018.

[3] Suyanto, Machine Learning Tingkat Dasar dan Lanjut, Bandung: Informatika, 2018.

[4] M. Z. Alom, T. M. Taha, C. Yakopcic, S. Westberg, P. Sidike, M. S. Nasrin, B. C. V. Essen, A. A. S. Abdul and V. K. Asari, "The History Began from AlexNet: A Comprehensive Survey on Deep Learning Approaches," Cornell University Libary's arXiv.org, pp. 1-37, 2018.

[5] C. T. Ferraz and J. H. Saito, "A Comprehensive Analysis of Local Binary Convolutional Neural Network for Fast Face Recognition in Surveillance Video," in Proceedings of the 24th Brazilian Symposium on Multimedia and the Web, Salvador, 2018.

[6] A. K. Datta, M. Datta and dkk., Face Detection and Recognition, CRC Press, 2015.

[7] S. Gollapudi, Learn Computer Vision Using OpenCv: With Deep Learning CNNs and RNNs, Apress, 2019.

[8] Y. Sun, B. Xue, M. Zhang and G. G. Yen, "Evolving Deep Convolutional Neural Networks for Image Classification," IEEE Transactions on Evolutionary Computation, pp. 1-14, 2019.

[9] L. M. Azizah, S. F. Umayah, S. Riyadi, C. Damarjati and N. A. Utama, "Deep learning implementation using convolutional neural network in mangosteen surface defect detection," IEEE International Conference on Control System, Computing and Engineering (ICCSCE), pp. 243- 246, 2017.

[10] N. Aloysius and M. Geetha, "A review on deep convolutional neural networks," International Conference on Communication and Signal Processing (ICCSP), pp. 588-592, 2017. 
[11] Y. Gan, "Facial Expression Recognition Using Convolutional Neural Network," in Proceedings of the 2nd International Conference on Vision, Image and Signal Processing, Las Vegas, 2018. 